\begin{tabular}{ll}
\hline \hline MINING AND METALLURGY INSTITUTE BOR & ISSN: 2334-8836 (Štampano izdanje) \\
UDK: 622 & ISSN: 2406-1395 (Online) \\
\hline \hline
\end{tabular}

\title{
POSSIBILITY OF USE THE KAONA QUARTZITE (EAST SERBIA) ${ }^{* *}$
}

\begin{abstract}
The locality of "Kornjica" is located in the area of the village Kaona, about $5 \mathrm{~km}$ from the main road Majdanpek-Kučevo-Požarevac-Belgrade, or about $10 \mathrm{~km}$ west of Kučevo. Quartzites and quartz metaconglomerates on the surface of about $2 \mathrm{~km}^{2}$ were studied at the site "Kornjica". Quartzites and quartz metaconglomerates build a package of layers of thickness about $150 \mathrm{~m}$, which are white, solid, compact and cores. The thickness of pure quartzites is 30 to $40 \mathrm{~m}$, which is multiple interlayered with the other quartzites and quartz metaconglomerates. The rocks are of different compactness and composition. Sometimes, the relict pseptic structures are observed in them as well as the quartz-serie binders. From the existing three horizons of quartzite and quartz metaconglomerates (Kalenić, HadžiVukovic, 1974), the oldest package occurs at Kaona, which is considered to signify the passage of vendor in the Cambrian. The field geological explorations, petrological tests, chemical tests, physicalmechanical tests and directed technological research (in the laboratory conditions) were carried out. The obtained results of research, along with the already existing data, have enabled the definition of quartzite deposits near Kaona, as well as determining the possibility of using these rocks as the mineral raw materials (whose quality would meet the prescribed standards for use in metallurgy, refractory and chemical industries).

Keywords: quartzite and quartz metaconglomerates, petrographic characteristics, physical-mecha-
\end{abstract} nical characteristics, chemical characteristics, quartzite quality, East Serbia

\section{INTRODUCTION}

The location of "Kornjica" is located, by air line, about $10 \mathrm{~km}$ in the west of Kučevo, in the attic of Kaona village (East Serbia, Figure 1). This orographic region belongs to the South Carpathians; it is a hydrographic part of the central river basin of the river Pek,and it administratively belongs to the Branicevo District (Municipality of $\mathrm{Ku}$ čevo). For the immediate vicinity of the explored area, besides the river Pek that flows in the immediate vicinity, the Kaonski stream is of great importance. The metamorphic complex in the Kaona region ( $\mathrm{Ka}$ lenić, Hadži - Vukovic, 1974) was insufficiently studied from the aspect of quartzite exploration as the quartz mineral resource. In order to solve the set problems, in addition to the field observations, a detailed geological exploration the metamorphic complex was carried out on an area of about

\footnotetext{
* Mining and Metallurgy Institute Bor, Zeleni bulevar 35, 19210, Serbia,

e-mail: sladjana.krstic@irmbor.co.rs

** This paper is the result of the Project No. TR 33021 "Research and Monitoring the Changes of the Stress Strain State in the Rock Mass "In-Situ" around the Underground Rooms with Development of Models with Special Reference to the Tunnel of the Krivelj River and Pit Bor", funded by the Ministry of Education, Science and Technological Development of the Republic of Serbia
}

No. 1-2, $2017 \quad 1 \quad$ Mining \& Metallurgy Engineering Bor


$0.60 \mathrm{~km}^{2}$. Interpretation of the obtained results of exploration, along with already existing data, has enabled defining the quartzite deposit near Kaona, development the necessary graphic and other documentation, as well as determining the possibility of applying these rocks as mineral raw materials.

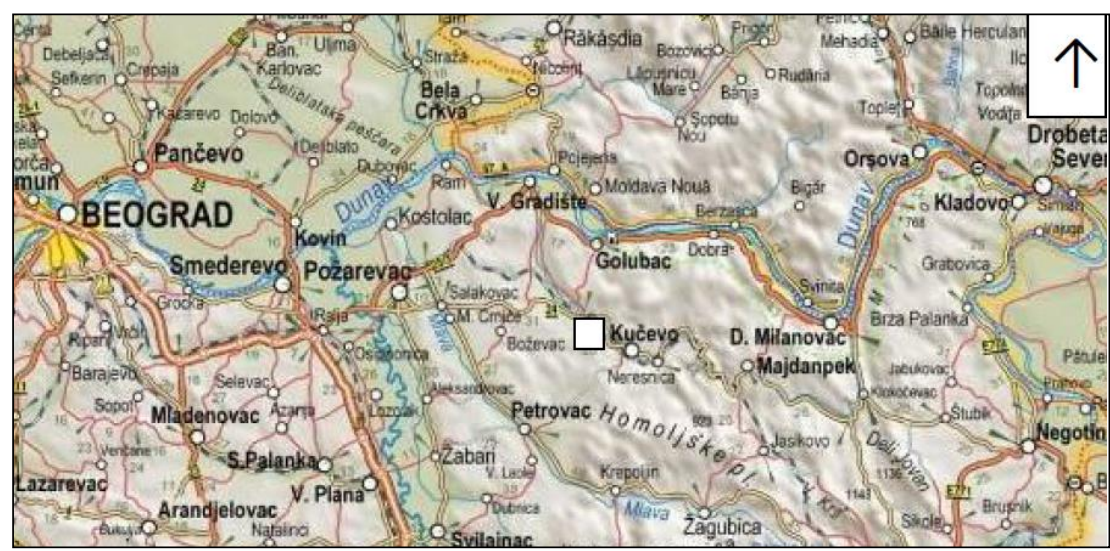

Figure 1 Geographical position of the Kaona quartzites

\section{BASIC GEOLOGICAL DATA AND OVERVIEW OF PREVIOUS EXPLORATIONS}

The Kaona area belongs to the Kucevo OGK leaf, scale 1: 100,000 with the mark L34-128. The leaf Kučevo is located between $44^{\circ} 20^{\prime} 4$ and $44^{\circ} 40^{\prime}$ of the north latitude, and $21^{\circ} 30^{\prime}$ and $22^{\circ} 0^{\prime}$ of the east longitude GMT. Includes Braničevo, upper river Mlava, Stig, a part of Homolje and North Kučaj.The boundaries of the explored area are located in a part of the Kladurovo leaf (L-34-128$\mathrm{Ca}$, scale 1: 25,000). A wider surrounding of the explored area (Figure 2) is built of the Palaeozoic, Mesozoic and Kenoosic rocks (Kalenić, Hadži-Vuković 1974).

In recent years, the paleozoic metamorphic complex in the Kaona area has been relatively little investigated by our and foreign researchers who have been dealing with the individual research in terms of sedimentology (Kalenić, Milosavljević, 1987, 1988), paleontology (Djajić 1992), magmatism or metamorphism (Ivanović. 2000). Djajić states that the original sediments were deposited in the marine environment, probably by the end of Siluria and the beginning of Devon, and the spores of the first primitive land-based plants were together with the other material transported from the surrounding land or island into the deposition basin. Milosavljevic (1992) dealt with the quartzites of Turian and Sena in detail. She determines the quartzites of the Moravian Zone as a part of the Serbian-Macedonian mass that stretche from the Danube to Vlasina Lake, in a narrow zone of about $250 \mathrm{~km}$ in length. She describes quartizites as the rocks that appear as one, two or more successive discontinuous hori-zons (a few tens of meters thick) by the palinopalinological analyses of the proven lower Devon age.

Petrologic - sedimentological studies of quartzites have proved that they are metamorphic sediments (quartzites of the Moravian Zone according to the preserved relict structures and textures are determined as the 
primary conglomerates and sand-stones formed by the shallow water sedimentation). Metamorphism caused the recrystallization and loss of contours of the primary grains and fragments. A large amount of silicon binder is present pri-marily because of isochemical and exoechemic dissolution and redissolution of silicon during and after diogenesis. By analyzing the quartz pebbles, detritic minerals (primarily zircon), it has been proved that the clastic quartzite material originated of the rocks from the metamorphic region. The occurrence of chloritoids and pyrophyllites in the matrix of metaclastite of the Moravian zone were studied by Milovanović et al. (1994). These authors believe that chloritoide, pyrophilic and chlorite were formed at temperatures around $350^{\circ} \mathrm{S} \pm 50^{\circ} \mathrm{S}$ and pressures of 2-3 kbar.

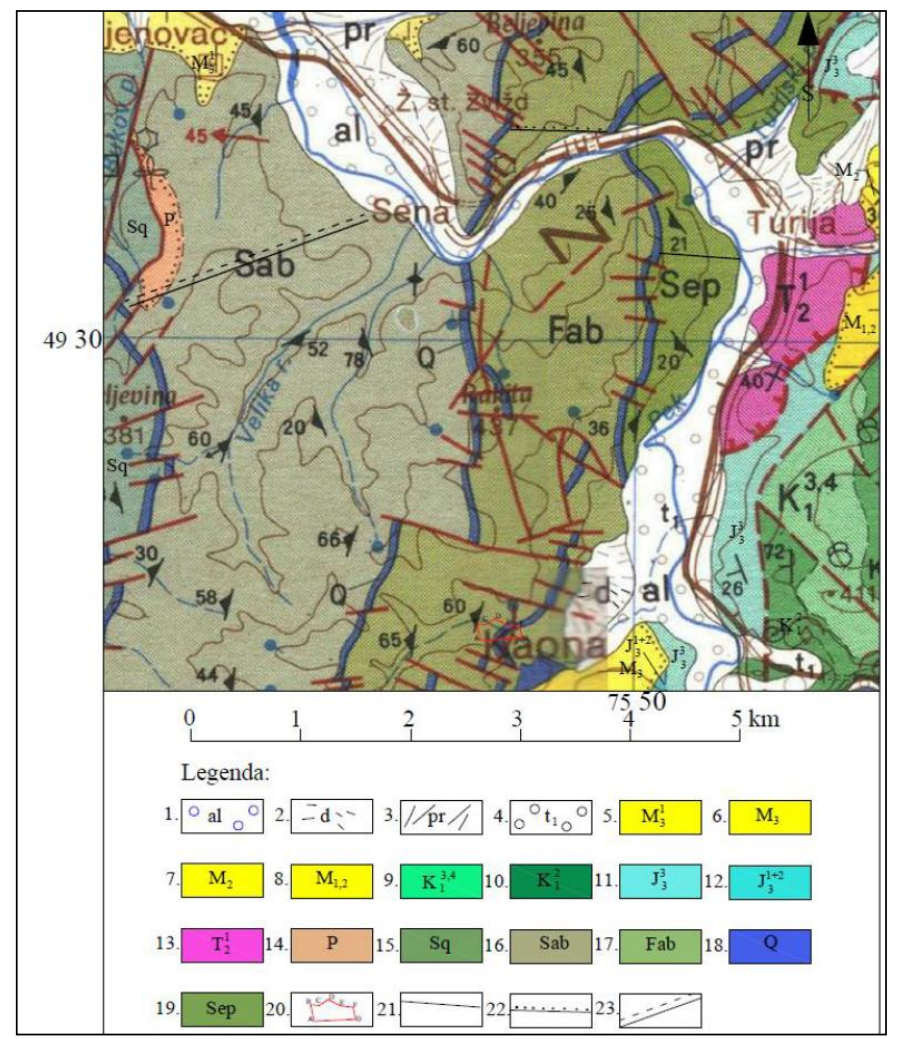

Figure 2 Geological map of a wider area of explored Kaona territory (Kučevo a part of the leaf Kučevo 1:100 000 (Kalenic, Hadzi Vukovic, 1974) with a view of geological columns (Kalenic et al. 1987)

Legend: 1. alluvium; 2. deluvium; 3. proluviums; 4. river terrace; 5. gravel, sand, clay and limestone; 6. sands and gravels; 7. conglomerates, sandstones, clays, tuffs and coal; 8. conglomerates, shales with coal and marl; 9. massive and banked limestones; 10. marl, marly limestone and limestone with a pink bump; 11. banked and layered limestone, marl limestone and marl; 12. banked and plate limestones with pink bumps; 13. dolomitic limestone and limestone; 14. red sandstones and conglomerates; 15. metapsamites and metadiabasites; 16. acidic metavoclanites, metapelites and metapsamites; 17. metabasites and filitoids; 18. quartzites and quartz conglomerates; 19. sericite schists; 20. exploration area of the Kaona quartzites; 21. location of the geological column Kaona-Turija; 22. location of the geological column Sena-Turija, and 23. location of the geological column Sena-Mišljenovac 
The metamorphic complex in the area Kaona has been insufficiently studied from the aspect of quartzite research as a quartz mineral resource. In the period 1988 - 1990 (Bugarin), a quartzite prospectus was carried out in the area of Kaona, a narrow locality of the "Kornjica" (a detailed geological map $1: 2.500$, the surface area of $2 \mathrm{~km}^{2}$ and 200 ha, was made, covering the area where the quartzite outcrops were observed.) In the same proportions, a structural map of the locality of Kornjica was made. Systematic research of the regional character included: recognition and geological mapping of the terrain for development a geological map of $1: 10.000$. In geological mapping, the samples were taken for mineralogical-petrological tests as well as for laboratory tests of chemical composition of quartzite. It is determined by the geological researches that it is a quartzite series of thickness up to $150 \mathrm{~m}$, in the form of packages (layers), whose quality differs macroscopically by compactness, thickness, grain size distribution, etc. The scope and type, as well as the density of applied exploration works was not satisfactory to talk about the reserves of higher categories on which the future exploitation is based.

\subsection{Geological Characteristics of the Quartzite Deposit Kaona}

The area of field of the quartz raw material, Kaona, was built mainly of crystalline shales, within which quartzites, quartz metaconglomerates and quartz metasands are located (Figure 3). The southeastern and southwestern parts of this terrain are formed by the sedimentary structures of the Miocene age.

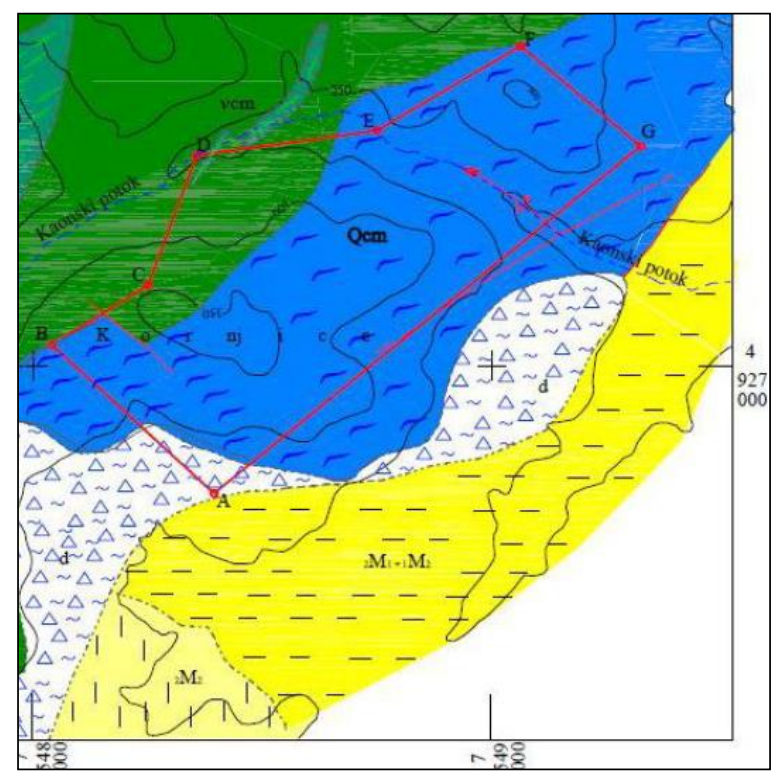

Figure 3 Geological map of the explored area Kaona 1:10 000 (a part of the leaf Kladurovo 2-L-34-128-Ca 1:25 000)

Legend: 1.

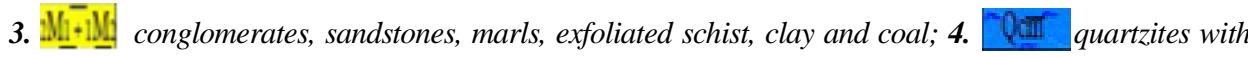
metaconglomerates and quartz conglomerates; 5. vell metamorphosed gabbro; 6.1 B morphosed diabase and gabrodiabase; 7. Sortm quartz-sericite-chlorite schists and graphitic schists, 8. ' anticline; $9 . \square$ fault; 10. $)^{5}$ exploration area 
The deposit Kaona is located at the forehead of putting on the proterozoic and old paleozoic complexes of the Moravian zone, over the Mesozoic structures of the Golubac-Gornjak structural unit. If the Mesozoic sediments east of Kaona are excluded, and in our case they represent only the ground on which the Vend-Cambrian formation is drawn, then the geological situation is quite simple.

By studying quartzite, quartz metaconlomerates and quartz metasandstones of Kaona, it was observed that, in the vertical column, three identical zones can be separated, thickness of about $80 \mathrm{~m}$. From the existing three horizons of quartzite, disintegrated quartzite, and quartz metaconglomerates and quartz metasandstones, the oldest one occurs near Kaona that denotes the passage of proterozoic (venda) into the cambium (Kalenić, Hadži-Vuković, 1974).

Quartzites are the metamorphic structures that originate from quartz sands, quartz sandstones and quartz conglo-merates, which underwent changes in both methane and cement binder due to the regional metamorphism, both the base mass and cement binder. In spite of the fact that the proportion of cement masses in the higher horizons is not large, however, quartzites of Kaone are a better quality mineral raw material as cleaner.

\section{MATERIAL AND METHODS OF QUARTZITE TESTING AS THE MINERAL RAW MATERIAL}

Within testing the quality of quartz mineral raw material, the earlier results of systematic testing of regional character (period from 1988 to the end of 1989) were used, by reconnaissance and geological mapping of the terrain surface, as well as development of shallow trenches. Sampling of trenches was carried out by outbreaking a rough furrow (in total 23 samples were taken, which were analyzed on: $\mathrm{SiO}_{2}$, $\mathrm{Al}_{2} \mathrm{O}_{3}, \mathrm{Fe}_{2} \mathrm{O}_{3}, \mathrm{Fe}_{2} \mathrm{O}_{3}$ and $\mathrm{CaO}$ ).

The basic method of detailed geological exploration the deposit of quartz raw material Kaon was the exploration depth drilling with coring. The Kaona deposit at Kucevo was explored by vertical cross-sections (Figure 4), exploration drilling from the terrain surface (9 vertical exploration drillholes). Total of 419.0 meters was drilled.

Geological works followed the exploration drilling; they were performed simultaneously and continued after them.

The applied test methods are reduced to sampling the exploration drillholes. Tests were taken for laboratory (chemical), petrological, and physico-mechanical tests. Testing of the exploration drillholes cores was carried out in parallel with the geological mapping the core of drillhole. For laboratory test (chemical) tests, individual samples were taken along the entire length of the drillholes (except the humus cover interval). The lengths of sampling the cores from drillholes were $2 \mathrm{~m}$ (exceptionally, 1.8 $\mathrm{m}$ or $2.5 \mathrm{~m}$ when, due to the lack of core, the two-meter interval could not be accurately determined). Total of 198 individual samples were taken. Total of 19 samples was taken for petrological testing of samples from exploratory drillholes (Table 6) of which 11 preparations were made. For laboratory tests of physical-mechanical properties, total of 104 samples was taken. The taken samples were analyzed in the MMI Bor laboratories (chemical tests, mineralogical-petrological, geomechanical tests and targeted technological tests). 


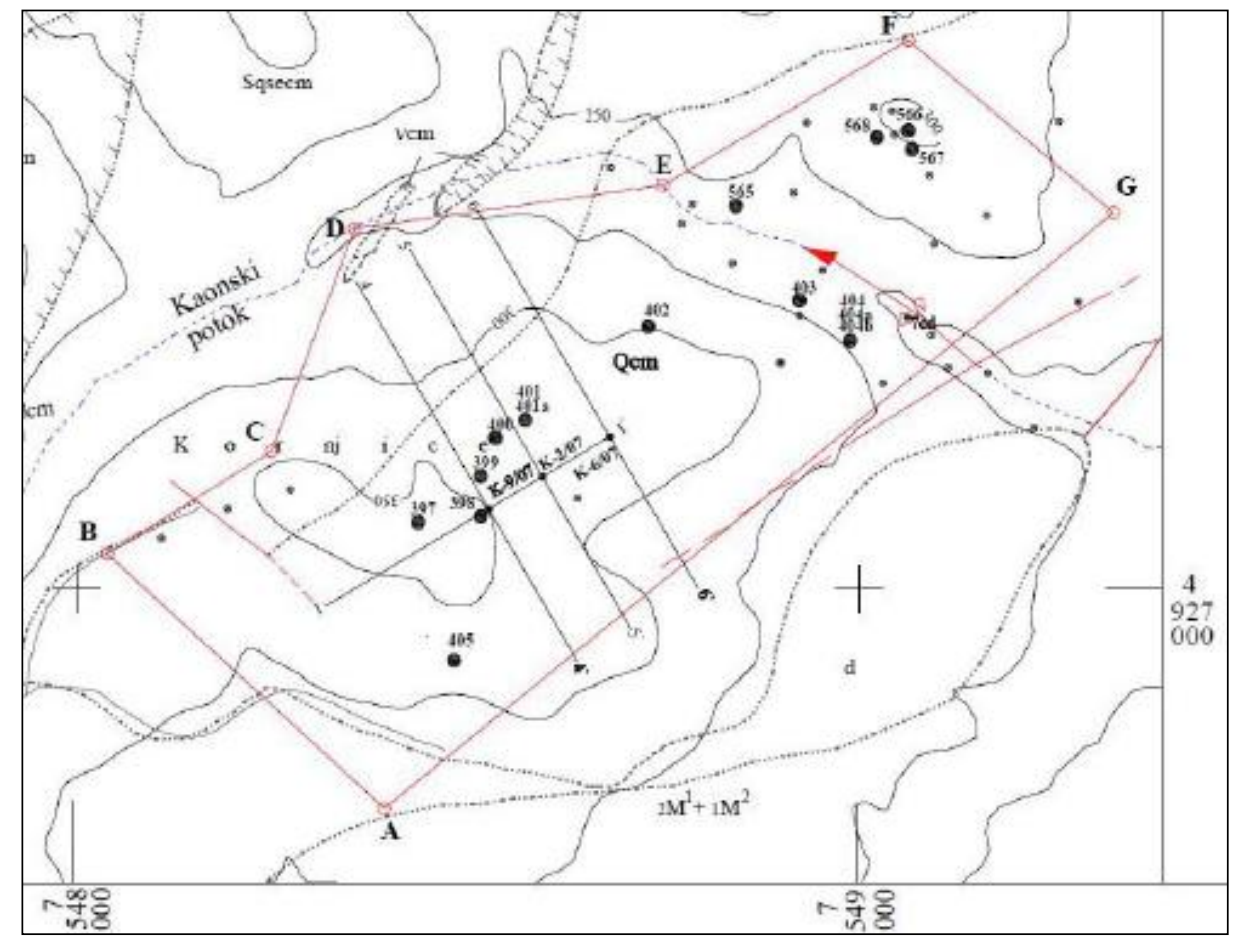

Figure 4 Map of sampling the site Kornjice, 1:10 000 (a part of the leaf Kladurovo 2 L-34-128-Ca)

Legend: $\bullet A B C D E F G$ - Breakpoints of the exploration area of quartz mineral resources; $\bullet 404-$ petrological prospecting point; • - chemical test outcrops in 1988; • K-9/07 - petrological tests of exploration drillholes; 5-5'- Exploratory cross section

\section{RESULTS OF TESTING \\ THE QUALITY OF MINERAL \\ RAW MATERIAL}

\section{1 Chemical Characteristics of the Kaona Quartzite}

The basic criterion for contouring the productive interval, i.e. determining the internal contour of the deposit, was a minimum content of $\mathrm{SiO}_{2}$ of $85 \%$ and a maximum content of harmful substances: $\mathrm{Al}_{2} \mathrm{O}_{3}$ to $5.0 \%, \mathrm{Fe}_{2} \mathrm{O}_{3}$ to $5.0 \%$ and $\mathrm{CaO}$ to $5.0 \%$.

Based on the demands of certain branches of the quartz raw material industry, the existence of parts of deposits with different $\mathrm{SiO}_{2}$ medium contents, which had to be taken into account in designing the model, were identified, so that three quality classes (Table 1) were separated within the base. 
Table 1 Quality classes of the deposit Kaona

\begin{tabular}{|c|c|c|c|c|}
\hline \multirow{2}{*}{ Quality class } & \multicolumn{4}{|c|}{ Content of useful and harmful components (\%) } \\
\cline { 2 - 5 } & Useful components & \multicolumn{3}{|c|}{ Harmful components } \\
\cline { 2 - 5 } & $\mathbf{S i O}_{\mathbf{2}}$ & $\mathbf{F e}_{\mathbf{2}} \mathbf{O}_{\mathbf{3}}$ & $\mathbf{A l}_{\mathbf{2}} \mathbf{O}_{\mathbf{3}}$ & $\mathbf{C a O}$ \\
\hline QI & $>93.00$ & mah 5.00 & mah 5.00 & mah 5.00 \\
\hline QII & $90.00-93.00$ & mah 5.00 & mah 5.00 & mah 5.00 \\
\hline QIII & $85.00-90.00$ & mah 5.00 & mah 5.00 & mah 5.00 \\
\hline
\end{tabular}

Witin testing the quality of quartz mineral raw material, the previous results of systematic testing of a regional character were also used. Sampling of a trench was done by outbreaking a rough furrow. The soformed individual test sample was analyzed on: $\mathrm{SiO}_{2}, \mathrm{Al}_{2} \mathrm{O}_{3}, \mathrm{FeO}, \mathrm{Fe}_{2} \mathrm{O}_{3}$ and $\mathrm{CaO}$ (total of 23 samples were taken). The $\mathrm{SiO}_{2}$ content ranges from a minimum of $93.82 \%$ to a maximum of $98.22 \%$, and a mean content of $96.32 \%$. The $\mathrm{Al}_{2} \mathrm{O}_{3}$ content varies from a minimum of $0.10 \%$ to a maximum of $1.63 \%$, and a mean content of $0.68 \%$. The $\mathrm{Fe}_{2} \mathrm{O}_{3}$ content varies from a minimum of $0.34 \%$ to a maximum of $2.12 \%$, and a mean content of $0.96 \%$. The $\mathrm{FeO}$ content varies from a minimum of $0.37 \%$ to a maximum of $1.01 \%$, and a mean content of $0.64 \%$. The content of $\mathrm{CaO}$ from the taken samples is in traces. Three composite samples were formed from the same samples. Composite samples were analyzed on: $\mathrm{TiO}_{2}, \mathrm{Cr}_{2} \mathrm{O}_{3}$, $\mathrm{MgO}, \mathrm{K}_{2} \mathrm{O}, \mathrm{Na}_{2} \mathrm{O}$, and loss by ignition. The results of chemical analyses of composite samples are shown in Table 2.
In the laboratory conditions, the chemical analyses of individual samples from drillholes were carried out on useful and harmful components: $\mathrm{SiO}_{2}, \mathrm{Al}_{2} \mathrm{O}_{3}, \mathrm{Fe}_{2} \mathrm{O}_{3}$, $\mathrm{CaO}$. From the individual samples, the composite samples (total of 41) were formed, which were tested for $\mathrm{SiO}_{2}, \mathrm{Al}_{2} \mathrm{O}_{3}$, $\mathrm{Fe}_{2} \mathrm{O}_{3}, \mathrm{CaO}, \mathrm{MgO}$, S-total, $\mathrm{SO}_{3}, \mathrm{TiO}_{2}, \mathrm{~K}_{2} \mathrm{O}$, $\mathrm{Na}_{2} \mathrm{O}, \mathrm{Cr}_{2} \mathrm{O}_{3}$ and loss by ignition.

A composite sample was obtained combining the material with five consecutive, individual samples $\mathrm{p}$ (ten-meter interval). The mean content of useful and harmful components in the drillholes, calculated on the basis of chemical analyses of individual samples, were obtained as weighted values by the length of testing interval, while the mean content was calculated for the whole deposit as the weighted value of the entire sampling interval (Table 3). The mean content of useful and harmful components, calculated by the MINEX 5.2.1 program package, from the composite samples by the selected quality classes, depending on the require-ments of application the mineral raw material, are shown in Table 4 for the whole deposit.

Table 2 Results of outcrops sampling (composite test)

\begin{tabular}{|c|c|c|c|c|c|c|}
\hline \hline \multirow{2}{*}{ Sample designation } & \multicolumn{7}{|c|}{ Medium content (\%) } \\
\cline { 2 - 7 } & $\mathbf{T i O}_{\mathbf{2}}$ & $\mathbf{C r}_{\mathbf{2}} \mathbf{O}_{\mathbf{3}}$ & $\mathbf{M g O}$ & $\mathbf{K}_{\mathbf{2}} \mathbf{O}$ & $\mathbf{N a}_{\mathbf{2}} \mathbf{O}$ & $\mathbf{G . Z ̌ . ~}$ \\
\hline $1-13 \mathrm{AB}$ & 0.033 & 0.000 & 0.027 & 0.172 & 0.033 & 0.390 \\
\hline $10-20 / \mathrm{CD}$ & 0.033 & 0.027 & 0.015 & 0.183 & 0.031 & 0.140 \\
\hline 17-A; 17-B; 17-C & 0.080 & 0.000 & 0.029 & 0.251 & 0.037 & 0.280 \\
\hline \hline
\end{tabular}


Table 3 Medium content of useful and harmful components (by drillholes, from individual tests)

\begin{tabular}{|c|c|c|c|c|}
\hline \hline \multirow{2}{*}{$\begin{array}{c}\text { Drillhole } \\
\text { designation }\end{array}$} & \multicolumn{4}{|c|}{ Medium content (\%) } \\
\cline { 2 - 5 } & $\mathbf{S i O}_{\mathbf{2}}$ & $\mathbf{F e}_{\mathbf{2}} \mathbf{O}_{\mathbf{3}}$ & $\mathbf{A l}_{\mathbf{2}} \mathbf{O}_{\mathbf{3}}$, & $\mathbf{C a O}$ \\
\hline \hline $\mathrm{K}-1 / 07$ & 96.222 & 1.766 & 1.433 & 0.230 \\
\hline $\mathrm{K}-2 / 07$ & 93.405 & 1.601 & 3.051 & 0.118 \\
\hline $\mathrm{K}-6 / 07$ & 92.900 & 1.268 & 3.126 & 0.229 \\
\hline $\mathrm{K}-5 / 07$ & 94.848 & 1.686 & 1.852 & 0.451 \\
\hline $\mathrm{K}-17 / 07$ & 95.293 & 1.433 & 1.663 & 0.113 \\
\hline $\mathrm{K}-11 / 07$ & 92.831 & 1.926 & 2.485 & 0.107 \\
\hline $\mathrm{K}-20 / 07$ & 95.582 & 1.272 & 1.293 & 0.220 \\
\hline $\mathrm{K}-7 / 07$ & 94.213 & 1.691 & 1.845 & 0.271 \\
\hline $\mathrm{K}-9 / 07$ & 94.929 & 1.618 & 1.361 & 0.147 \\
\hline \hline Whole deposit & 94.442 & 1.569 & 2.013 & 0.215 \\
\hline
\end{tabular}

Table 4 Medium contents from composite tests by the quality classes, calculated by the software package MINEX 5.2.1.

\begin{tabular}{|c|c|c|c|c|c|c|c|c|c|c|c|}
\hline \multirow{2}{*}{ Quality class } & \multicolumn{11}{|c|}{ Medium content (\%) } \\
\hline & $\mathrm{SiO}_{2}$ & $\mathrm{Fe}_{2} \mathrm{O}_{3}$ & $\mathbf{A l}_{2} \mathbf{O}_{3}$ & $\mathrm{CaO}$ & MgO & $\mathrm{Na}_{2} \mathrm{O}$ & $\mathrm{K}_{2} \mathrm{O}$ & $\mathbf{S}$ & $\mathrm{TiO}_{2}$ & $\mathrm{SO}_{3}$ & $\mathrm{Cr}_{2} \mathrm{O}_{3}$ \\
\hline $\left.93 \% \mathrm{SiO}_{2}\right)$ & 95.19 & 1.45 & 1.63 & 0.23 & 0.12 & 0.09 & 0.33 & 0.16 & 0.13 & 0.42 & 0.08 \\
\hline QII $\left(90-93 \% \mathrm{SiO}_{2}\right)$ & 91.30 & 2.06 & 2.88 & 0.33 & 0.16 & 0.16 & 0.62 & 0.26 & 0.17 & 0.65 & 0.03 \\
\hline QIII $\left(85-90 \% \mathrm{SiO}_{2}\right)$ & 88. & 2.42 & 5.26 & 0.07 & 0.20 & 0.16 & 0.88 & 0.14 & 0.18 & 0.35 & 0.04 \\
\hline Whole deposit & 94.84 & 1.76 & 1.76 & 0.23 & 0.13 & 0.10 & 0.35 & 0.17 & 0.13 & 0.43 & 0.08 \\
\hline
\end{tabular}

\subsection{Petrographic Quartzite \\ Characteristics}

By a detailed observation and measuring on the outcropsa of rocks, the way of quartzite occurrence was determined, i.e. the exture properties of the same. Each outcrop is described, determined by coordinates and documented by the photographs on appearance and way of occurrence of these rocks (Figure 4). The samples of quartzite and quartz metaconglomerates were taken from the same outcrops for petrochemical testing (determining the mineral composition and rock structure and chemical testing.). Total of 14 samples were taken by the petrological prospecting the site Kornjica along the routes, parallel profiles, at a distance of 50 meters. Mineralogical - petrographic testing was carried out on selected samples from the drillholes (total of 11 samples) Total of 25 petrographic preparations were made. The examination of preparations was carried out on the Carl Zeiss/Jena polarization microscope, magnification up to $1200 \mathrm{x}$.

Based on the mineral composition, structure and texture, the Kaona quartztes are divided into: quartz metachonglomerates, massive quartzites, quartzite with sericity, cataclastic quartzite and quartzite with chloritide. Quartz metaconlomerates are dominant rocks in the researched area. They are of shrunken texture, build the banks of thickness up to a dozen meters (Figure 5). Macroscopic, on the ground, they 
are recognized by quartz pebbles, size of 2 to $5 \mathrm{~cm}$, which are deposited in a finegrained quartz mass. The rock is monomineral, built of quartz, granoblastic structure withof elements of blastopsamitic and porphyroblastic. Quartz occurs in grains of size from the tenth part up to several millimeters. Bigger quartz grains make for the most part the pebbles, size up to several millimeters, when the wall gets blastopsamitic and porphyroblastic structure.

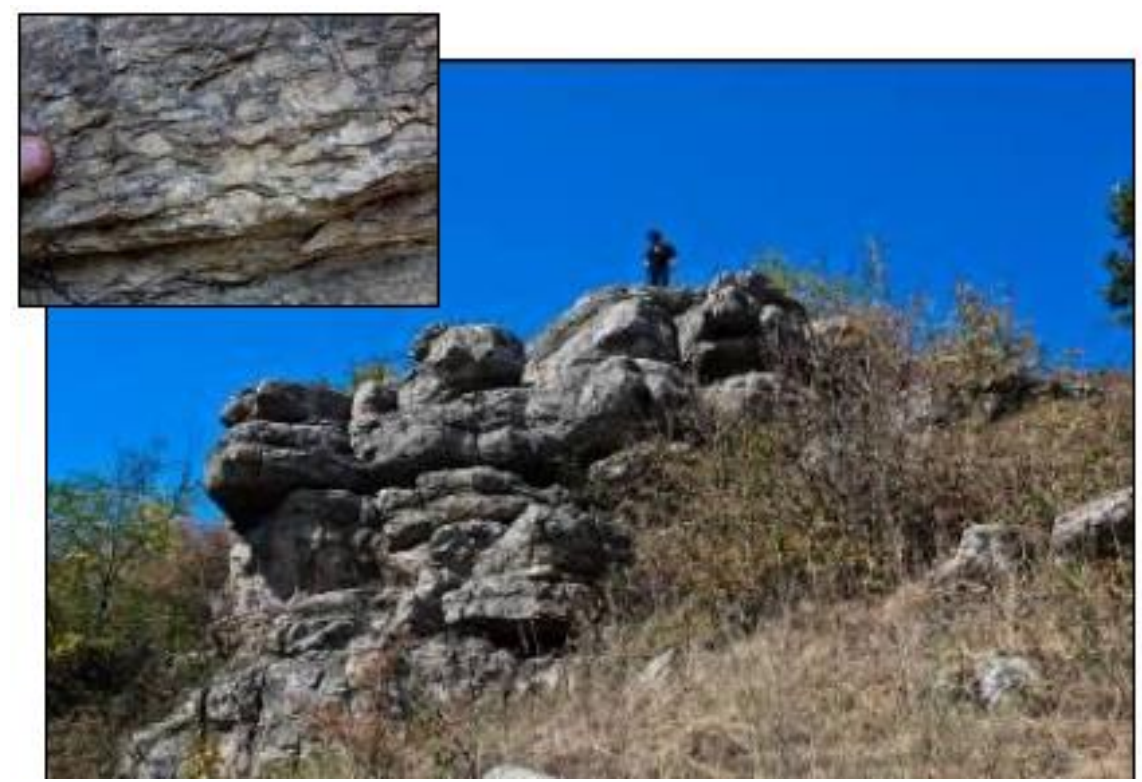

Figure 5 Banks of quartz metaconglomerates on the north-eastern part of Kornjica, above left a detail of the rock

\subsection{Physical - Mechanical Characteristics of Quarcite}

Physical-mechanical testing of samples from the exploratory drillholes (104 pcs.) was carried out on prepared test samples according to the valid standards for each type of test or according to the recommendations of the International Society for Rock Mechanics (ISRM). The following physical properties were determined on quartzite and quartz sand samples: humidity $\mathrm{v}=11.40 \%$, specific gravity or bulk density of solid particles $\gamma_{\mathrm{s}}=18.84 \mathrm{kN} / \mathrm{m}^{3}$, volume weight $\gamma=16.83 \mathrm{kN} / \mathrm{m}^{3}$, porosity $\mathrm{n}=3.58 \%$, velocity of longitudinal wave propagation
$\mathrm{VL}=4.123 .43 \mathrm{~m} / \mathrm{s}$. From the mechanical parameters, the following were tested: uniform pressure strength $\sigma \mathrm{p}=93.89 \mathrm{Mpa}$, and shear resistance parameters (cohesion $\mathrm{C}=25.57 \mathrm{MPa}$, and angle of internal friction $\left.\varphi=27.88^{\circ}\right)$.

\subsection{Granulometric Characteristics of Quarcite}

Testing the granulometric composition of the quartz mineral raw material from the Kaona deposit at Kučevo was carried out by 
two methods. The first method is to test the grain size distribution of the composite samples. Composite samples were formed according to the quality classes for each individual drillhole (Figure 6). The second method of testing consisted in testing the grain size distribution of each individual sample from all drillholes. The grain size distribution the samples of the quartz mineral raw material of the Kaona deposit is characterized Kaon deposit that fine classes $(-0.212+0 \mathrm{~mm})$ and coarse classes $(+4 \mathrm{~mm})$ participate with about $10-30 \%$. Classes $-4+$ $0,212 \mathrm{~mm}$ prevail, with a share of $70-90 \%$.

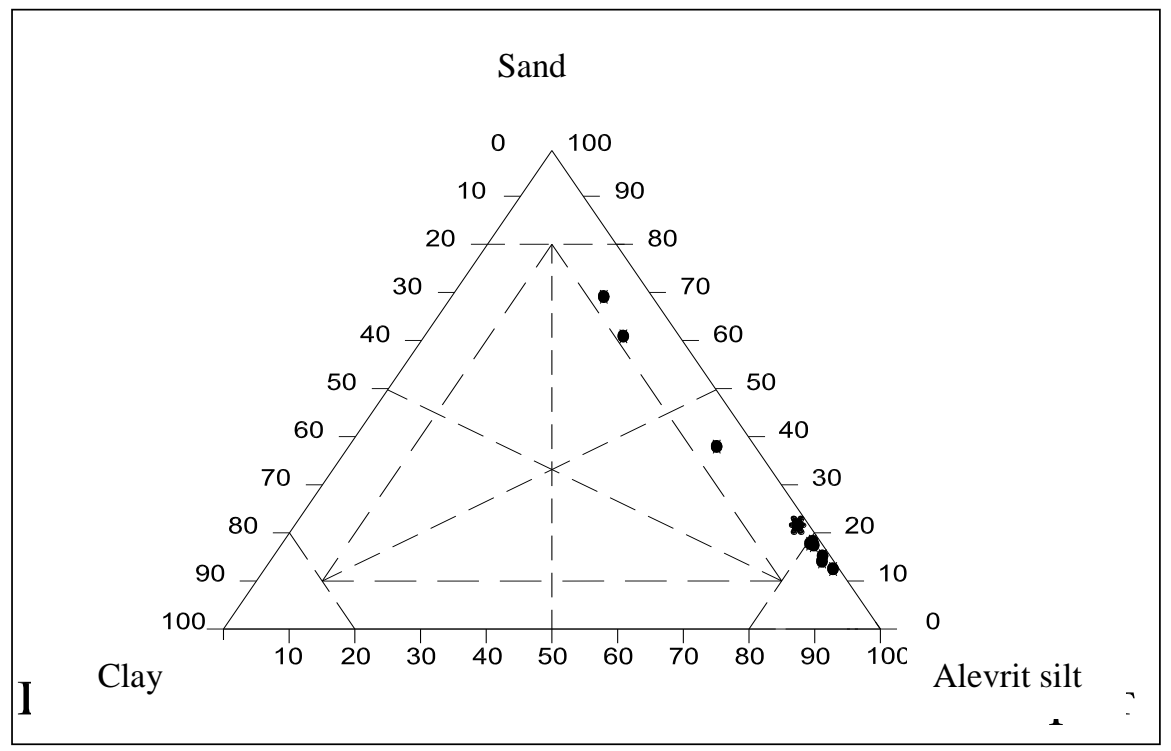

Figure 6 Three-component diagram of particle size distribution of composite samples

\subsection{Results of direct technological quarcite testing}

The direct technological tests (in order to determine the adequate technology to enable the cheapest production of commercial products through laboratory testing of disintegration, screening and atry sand washing), have resulted in a technological scheme for processing the quartz mineral raw materials in the Kaona deposit. A technological sample was formed of materials of all quality classes (run-of-mine raw material $=$ minimal content of $\mathrm{SiO}_{2} 85 \%$ and maximum content of harmful substances:
$\mathrm{Al}_{2} \mathrm{O}_{3}$ to $5.0 \%, \mathrm{Fe}_{2} \mathrm{O}_{3}$ to $5.0 \%$ and $\mathrm{CaO}$ to $5.0 \%$ ) and the results of these direct technological tests are shown in Tables 5 and 6 . The proposed technological scheme for processing the quartz mineral raw materials for the Kaona deposit (Milanović et al., 2009, 2010) contains the primary disintegration into a washing drum, and the secondary disintegration in the atry washing equipment is omitted (based on the achieved laboratory results by simulation the process of atry washing). 
Table 5 Content of useful and harmful components in the useful fractions of deposit

\begin{tabular}{|c|c|c|c|c|c|c|c|c|}
\hline $\begin{array}{c}\text { Particle size } \\
\text { distribution }\end{array}$ & $\mathbf{S i O}_{\mathbf{2}}$ & $\mathbf{A l}_{\mathbf{2}} \mathbf{O}_{\mathbf{3}}$ & $\mathbf{F e}_{\text {-uk }}$ & $\mathbf{K}_{\mathbf{2}} \mathbf{O}$ & $\mathbf{N a}_{\mathbf{2}} \mathbf{O}$ & $\mathbf{T i O}_{\mathbf{2}}$ & $\mathbf{C r}_{\mathbf{2}} \mathbf{O}_{\mathbf{3}}$ & $\mathbf{G . \check { Z }}$ \\
\hline $\mathbf{9 m})$ & \multicolumn{8}{|c|}{$\mathbf{\%}$} \\
\hline$-30+2.362$ & 96.33 & 1.62 & 0.93 & 0.49 & 0.052 & 0.19 & 0.10 & 0.053 \\
\hline$-2.362+0.63$ & 97.60 & 0.95 & 0.67 & 0.18 & 0.034 & 0.068 & 0.050 & 0.35 \\
\hline$-0.63+0.106$ & 96.13 & 1.39 & 0.90 & 0.26 & 0.057 & 0.15 & 0.11 & 0.98 \\
\hline$-0.106+0.000$ & 88.45 & 5.46 & 1.60 & 0.66 & 0.17 & 1.23 & 0.39 & 1.95 \\
\hline
\end{tabular}

Table 6 Physical-chemical characteristics of the run-of mine raw material, Kaona

\begin{tabular}{|l|c|c|}
\hline \multicolumn{3}{|c|}{ PHYSICAL - CHEMICAL CHARACTERISTICS } \\
\hline Bond's index - balls & $\mathrm{Wi}(\mathrm{kWh} / \mathrm{t})$ & 12.71 \\
\hline Bulk density of dry sample & $\gamma_{\mathrm{s}}\left(\mathrm{kg} / \mathrm{m}^{3}\right)$ & $1,102.6$ \\
\hline Bulk density of wet sample & $\gamma_{\mathrm{v}}\left(\mathrm{kg} / \mathrm{m}^{3}\right)$ & $1,363.83$ \\
\hline Rough moisture content & $v_{\mathrm{g}}(\%)$ & 9.53 \\
\hline Density of sample & $\rho\left(\mathrm{kg} / \mathrm{m}^{3}\right)$ & 2,720 \\
\hline ELEMENT & CONTENT $(\%)$ & ANALYTICAL METHOD \\
\hline $\mathrm{SiO}_{2}$ & 95.22 & $\mathrm{G}$ \\
\hline $\mathrm{Al}_{2} \mathrm{O}_{3}$ & 1.53 & AAS \\
\hline $\mathrm{Fe}_{2} \mathrm{O}_{3}$ & 0.35 & AAS \\
\hline $\mathrm{K}_{2} \mathrm{O}$ & 0.069 & AAS \\
\hline $\mathrm{Na}_{2} \mathrm{O}$ & 0.37 & AAS \\
\hline $\mathrm{TiO}_{2}$ & 0.13 & ICP-AAS \\
\hline $\mathrm{Cr} \mathrm{O}_{3}$ & 0.035 & ICP-AAS \\
\hline $\mathrm{Fe}$ & 1.01 & AAS \\
\hline $\mathrm{G} . \check{Z}$. & 0.88 & G \\
\hline $\mathrm{pH}$ & 8.25 & \\
\hline
\end{tabular}

\section{DISCUSSION OF DIRECT \\ TECHNOLOGICAL QUARTZITE TESTING}

Quartz raw materials are used in: refractory industry, glass and ceramics industry, plastics industry, chemical industry (to obtain acid resistant materials, enamel for dishes), metallurgy (as fluxes, granulate production for metallurgical processing of ferro alloys), in casting industry (for molds and cores), construction, for production of silicate fillers, as well as the production of ferrosilicon (Table 7). The use of quartz raw materials depends on the quality (chemical composition) and physical-mechanical properties of the same.

The plan of mining exploitation of mineral resources (open pit mining) foresees the annual mining capacity of 150,000 t/year, commercial fractions or commercial products with application shown in Table 7, and 
the expected annual production balance mass of the annual production is shown in Table 8. The proposed technology and technological solutions have achieved the primary goal: to obtain several commercial products for use in various industrial branches by a relatively small investment (simpler technology).

Table 7 Fields of application the commercial size classes of quartz mineral resources

\begin{tabular}{|c|l|}
\hline \hline Size class (mm) & \multicolumn{1}{c|}{ Fields of application } \\
\hline \hline$-30.00+2.362$ & Construction, filter fillings, oil industry, air sand blasting \\
\hline$-2.326+0.630$ & Construction, filter fillings, oil industry, air sand blasting \\
\hline$-0.630+0.106$ & $\begin{array}{l}\text { Casting industry (very good), glass industry (VIII class), ceramic } \\
\text { industry (II class) }\end{array}$ \\
\hline$-0.106+0.053$ & $\begin{array}{l}\text { Construction industry (gas, concrete), chemical industry, extrac- } \\
\text { tive metallurgy, casting industry, construction }\end{array}$ \\
\hline$-0.053+0.000$ & Building ceramics \\
\hline
\end{tabular}

Table 8 Commercial products - expected balance of weight at the annual level, deposit Kaona

\begin{tabular}{|l|l|l|l|l|}
\hline \multicolumn{1}{|c|}{ Product } & \multicolumn{1}{|c|}{$\begin{array}{c}\text { Size class } \\
(\mathbf{m m})\end{array}$} & $\begin{array}{c}\text { Production } \\
(\mathbf{t} / \mathbf{h})\end{array}$ & \multicolumn{1}{|c|}{$\begin{array}{c}\text { Mass } \\
(\boldsymbol{\%})\end{array}$} & $\begin{array}{c}\text { Annual } \\
\text { production } \\
(\mathbf{t} / \mathbf{y e a r})\end{array}$ \\
\hline P1 & $-30+15$ & 3.24 & 9.08 & $13,617.60$ \\
\hline P2 & $-15+2.362$ & 5.23 & 14.65 & $21,976.66$ \\
\hline P3 & $-2.36+0.63$ & 16.29 & 45.61 & $68,418.75$ \\
\hline P4 & $-0.63+0.106$ & 9.54 & 26.70 & $40,041.56$ \\
\hline Waste & $-0.106+0.000$ & 1.41 & 3.96 & $5,945.43$ \\
\hline Capacity (Qyear) & 150,000 t/year (35,712 t/h) \\
\hline
\end{tabular}

\section{CONCLUSION}

Based on the results of detailed geological explorations (chemical, mineralogical petrological and geomechanical tests) and direct technological testing (in the laboratory conditions), the deposit of quartzite Kaona is included in the first groupof the "Quartzite and quartz sand deposits of uniform thicknesses and chemical - mineral composition with the reserves amounts to over 1,000,000 tons of mineral raw materials". The exploration works include a small part of the deposit, an area of about $0.57 \mathrm{~km}^{2}$, which indicates that the geological explo-rations of the deposit itself should be continued.
Due to the uneven quality of mineral raw materials of the Kaona deposit (chemical composition and physical - mechanical properties), the same can have limited application in the refractory industry, glass and ceramics industry, plastics indu-stry, chemical industry (to obtain acid resistant materials, enamel dishes), metallurgy (as fluxes, production of granules for metallurgical processing of ferro alloys), casting industry (for molds and cores), construction, for the production of silicate fillers, as well as the production of ferrosilicon. 


\section{REFERENCES}

[1] Bugarin M.: Project of Geological Exploration of Quartzites in the Kaona Area in 1989/1990, Copper Institute Bor (unpublished), 1989, (in Serbian)

[2] Bugarin M., Anđelković A.: Quartzite Exploration in the Kaona Area (Geodetic Study), Copper Institute Bor (unpublished), 2005, (in Serbian)

[3] Djajić S.: Report on Palaeoplinological Investigations by the Project "Crystalline Schists of the Serbian-Macedonian Mass-Geological Map of SFRY 1:50.000". Professional Docu-ments Fund Geozavod - "Gemini", Belgrade, 1992 (in Serbian)

[4] Ivanović M.: Petrology of Palaeozoic Metamorphic Rocks between the Rivers Mlava and Peak. Master thesis (unpublished); Belgrade, 2000 (in Serbian)

[5] Kalenić M., Hadži-Vukovic M., Proterozoic-paleozoic. Interpreter of OGC SFRY Leaf Kučevo 1: 100.000, Professional Documentation Fund Geozavoda-"Gemini", 1974, Belgrade (in Serbian)

[6] Kalenić M., Hadži-Vuković M. et al.: Interpreter for the Leaf Kučevo OGK SFRz 1: 100 000. Federal Geological Survey, Belgrade, 1980 (in Serbian)

[7] Kalenić M., Hadži-Vuković M. et al.: Leaf Kučevo L 34-128 OGK SFRJ 1: 100 000. Federal Geological Institute, Belgrade, 1980 (in Serbian)

[8] Kalenić M., Milosavljević M.: Final report on the microscopic examination of the preparations of the wall from the Lapovo leaf 1:25.000. Professional Documents Foundation Geozavoda "Gemini", Belgrade, 1987 (In Serbian)
[9] Kalenić M., Milosavljević M.: Annual Report on the Construction of the Geological Map of SFRY 1:50.000 Project B1, "Crystalline Shards of the Serbian - Macedonian Mass". Professional Documentation Fund Geozavoda "Gemini", Belgrade, 1988 (unpublished)

[10] Maksimović M., Ljubojev V., Krstić S.: Project of Geological Exploration of Quartz Raw Materials (Quartzite) in the Area Kaona near Kucevo in 2007. Mining and Metallurgy Institute Bor, 2007 (unpublished) (in Serbian)

[11] Maksimović M., Pačkovski G., Ljubojev V., Jovanović M., Marinković V., Krstić S.: Elaborate on Geological Exploration of Deposit of Quartz Mineral Raw Material Kaona near Kučevo in 2007, Mining and Metallurgy Institute Bor, 2009 (unpublished) (in Serbian)

[12] Milanović D. et al.: Feasibility Study for Separation of Quartz Sand from the Kaona Deposit near Kučevo, Mining and Metallurgy Institute, Bor, 2009 (unpublished) (in Serbian)

[13] Milanović D., Ignjatović M., Obradović Lj., Magdalinović S., Urošević D.: Separation of Quartz Mineral Raw Materials from the Kaona Deposit near Kučevo. Zbornik radova, $\mathrm{Ru}-$ darstvo 2010, Tara, May 210, p. 459 468 (in English);

[14] Miyashiro A.: Pressure and Temperature Conditions and Tectonic Significance of Regional and Ocean-Floor Metamorphism. Tectonophysic, 1972, V. 13, p. 141-159;

[15] Milovanović D., Milosavljević M., Kalenić M., Marshig V.: Chloritoide 
and Pyrophyllite and Metaclastic Rocks of the Morava Zone. Geologica Balcanica, 24/3, 31-39, Sofia,1994.

[16] Milosavljević M.: Quartzite and Quartzite Metaconglomerates of the Older Paleozoic Age in the Area between the Rivers Mlava and Peak. Trainee work (unpublihes); Belgrade, 1988 (in Serbian)
[17] Milosavljević M.: Solving the Genesis of Paleozoic Quartzites of the Moravian Zone, Master Thesis (unpublished); Belgrade, 1992 (in Serbian)

[18] Milosavljević M., Kalenić M.: Devon quartzites of Seine and Turia. Geol. Anali Balk. Pol., Book. LVI, Vol. 1, p. 53-67 Belgrade, 1992 (in Serbian) 